\title{
Preface
}

\section{Stem Cells are Finally Starting to Jell}

\author{
Cesar V. Borlongan* \\ Department of Neurosurgery and Brain Repair, University of South Florida College of Medicine, Tampa, FL 33612, \\ USA
}

The advent of stem cells as a tool to decipher the cell's biology and as a source of transplant therapy to correct aging and diseases has become a core research arena for tissue engineering and regenerative medicine. It is thus fitting that The Open Tissue Engineering and Regenerative Medicine hosts this volume dedicated to a pivotal source of stem cells - the umbilical cord's Wharton jelly. Much kudos go to lead editor Dr. Giampero La Rocca for organizing this special volume of the journal, comprising of pioneering scientists who have advanced the basic and translational applications of Wharton jelly-derived stem cells (La Rocca, TOTERMJ 2011).

A unique cell population of Wharton jelly that has been suggested as displaying the stemness phenotype is the mesenchymal stromal cells or MSCs. The prototypical feature of MSCs is their plastic adherence expressing a phenotypically defined set of surface markers inculding CD90, CD73 and CD105. Although MSCs have been harvested from many different tissues, novel considerations of tissue specificity may dictate the eventual fate of MSCs. In particular, MSCs' stemness and immune properties appear to be more robustly expressed and functional with fetal than adult-derived MSCs. To this end, the young age of Wharton jelly suggests that MSCs harvested from this fetal origin will exhibit a much more proliferative, immunosuppressive, and even therapeutically active stem cells than those isolated from older, adult tissue sources such as the bone marrow or adipose. The present compilation of milestone discoveries on Wharton jelly-derived stem cells should aid in further moving the field of cell biology and therapy towards clinical applications.

In this special volume, Dr. Conconi lays out the groundwork on the Wharton jelly's characterization by providing an

*Address correspondence to this author at the Department of Neurosurgery and Brain Repair, University of South Florida College of Medicine, Tampa, FL 33612 USA; Tel: 813-974-3988; Fax: 813-974-3078; E-mail: cborlong@health.usf.edu overview on the human umbilical cord [1]. Next, Dr. Kita focuses on the specific region of the umbilical cord lining and Wharton jelly that stem cell niches [2]. Dr. Prasanna then makes the case for the therapeutic utility of the Wharton jelly-derived stem cells emphasizing the regenerative and immunomodulatory potential of these cells [3]. The next set of papers details the different disease indications, namely, cancer therapy [4], liver disease [5], peripheral nerve repair [6], cardiovascular diseases [7], cartilage regeneration [8], and tendon injury repair [9]. To further maximize the isolation and differentiation of stem cells derived from Wharton jelly, the next set of studies describes optimization experimental protocols, such as the use of oxygen concentration and plating density [9], cardiac differentiation factors [10], and gestational abnormalities (i.e., diabetes mellitus) [11]. Finally, new frontiers in Wharton jelly research are discussed, including the identification of umbilical cordderived perivascular cells [12] and the use of magnetic resonance imaging in contrast labeled-umbilical cord stem cells [13]. Altogether, these studies offer authoritative views on what we know about Wharton jelly-derived stem cells, as well as provide insights on what the future holds for the cells' biological and therapeutic applications.

We are witnesses to the many tissue sources of stem cells. Here, we are given the many appealing features of a unique set of stem cells that jell - the Wharton jelly!

\section{ACKNOWLEDGEMENT}

The author extends appreciation to Ms. Loren E. Glover who provided excellent technical assistance in the final preparation of the manuscript.

\section{DISCLOSURES/CONFLICT OF INTEREST}

CVB is supported by NIH NINDS R01 NS071956-01 and James and Esther King Foundation for Biomedical Research Program Research Grant 6129101700, and receives 
research grant support for his projects on stem cell therapy from SanBio Inc., Celgene Cellular Therapeutics, KMPHC, and NeuralStem Inc.

\section{REFERENCES}

[1] Conconi MT, Di Liddo R, Tommasini M, Calore C, Parnigotto PP. Phenotype and differentiation potential of stromal populations obtained from various zones of human umbilical cord: an overview. Open Tissue Eng Regen Med J 2011; 4: 6-20.

[2] Jeschke MG, Gauglitz GG, Phan TT, Herndon DN, Kita K. Umbilical cord lining membrane and Wharton's jelly-derived mesenchymal stem cells: the similarities and differences. Open Tissue Eng Regen Med J 2011; 4: 21-7.

[3] Prasanna YS, Jahnavi, VS. Wharton's Jelly Mesenchymal stem cells as off-the -shelf cellular therapeutics: A closer look into their regenerative and immunomodulatory properties. Open Tissue Eng Regen Med J 2011; 4: 28-38.

[4] Tamura M, Kawabata A, Ohta N, Uppalapati L, Becker KG, Troyer D. Wharton's jelly stem cells as agents for cancer therapy. Open Tissue Eng Regen Med J 2011; 4: 39-47.

[5] Scheers I, Lombard C, Najimi M, Sokal EM. Cell therapy for the treatment of metabolic liver disease: an update on the umbilical cord derived stem cells candidates. Open Tissue Eng Regen Med J 2011; 4: 48-53.

[6] Kuroda Y, Kitada M, Wakao S, Dezawa M. Mesenchymal stem cells and umbilical cord as sources for Schwann cell differentiation: their potential in peripheral nerve repair. Open Tissue Eng Regen Med J 2011; 4: 54-63.

[7] Breymann C, Semonov O. Mesenchymal stem cells derived from Wharton's jelly and their potential for cardio-vascular tissue engineering. Open Tissue Eng Regen Med J 2011; 4: 64-71.

[8] Hollweck T, Hartmann I, Eblenkamp M, et al. Cardiac differentiation of human Wharton's jelly stem cells-experimental comparison of protocols. Open Tissue Eng Regen Med J 2011; 4: 95-102.

[9] Lo Iacono M, Anzalone R, Corrao S, et al. Perinatal and Wharton's jelly-derived mesenchymal stem cells in cartilage regenerative medicine and tissue engineering strategies. Open Tissue Eng Regen Med J 2011; 4: 72-81.

[10] López Y, Seshareddy K, Trevino E, Cox J, Weiss ML. Evaluating the impact of oxygen concentration and plating density on human Wharton's jelly-derived mesenchymal stromal cells. Open Tissue Eng Regen Med J 2011; 4: 82-94.

[11] Pierdomenico L, Lanuti P, Lachmann R, et al. Diabetes mellitus during pregnancy interferes with the biological characteristics of Wharton's jelly mesenchymal stem cells. Open Tissue Eng Regen Med J 2011; 4: 103-11.

[12] Emrani H, Davies JE. Umbilical cord perivascular cells: a mesenchymal cell source for treatment of tendon injuries. Open Tissue Eng Regen Med J 2011; 4: 112-9.

[13] Lange-Consiglio A, Corradetti B, Rutigliano L, Cremonesi F, Bizzaro D. In vitro studies of horse umbilical cord matrix-derived cells: from characterization to labeling for magnetic resonance imaging. Open Tissue Eng Regen Med J 2011; 4: 120-33.

(C) Cesar V. Borlongan; Licensee Bentham Open.

This is an open access article licensed under the terms of the Creative Commons Attribution Non-Commercial License (http://creativecommons.org/licenses/by$\mathrm{nc} / 3.0 /$ ), which permits unrestricted, non-commercial use, distribution and reproduction in any medium, provided the work is properly cited. 